\title{
Headmasters' Instructional Leadership and Its Relationship with Teachers Performance
}

\author{
Jamalullail Abdul Wahab, Ahmad Zamri Mansor*, Muhammad Hussin, Sharla Kumarasamy \\ Faculty of Education, Universiti Kebangsaan Malaysia, 43600 UKM Bangi, Malaysia
}

Received July 30, 2020; Revised October 7, 2020; Accepted October 30, 2020

\begin{abstract}
Cite This Paper in the following Citation Styles
(a): [1] Jamalullail Abdul Wahab, Ahmad Zamri Mansor, Muhammad Hussin, Sharla Kumarasamy, "Headmasters' Instructional Leadership and Its Relationship with Teachers Performance," Universal Journal of Educational Research, Vol. 8, No. 11A, pp. 97 - 102, 2020. DOI: 10.13189/ujer.2020.082112.
\end{abstract}

(b): Jamalullail Abdul Wahab, Ahmad Zamri Mansor, Muhammad Hussin, Sharla Kumarasamy (2020). Headmasters' Instructional Leadership and Its Relationship with Teachers Performance. Universal Journal of Educational Research, 8(11A), 97 - 102. DOI: 10.13189/ujer.2020.082112.

Copyright $\odot 2020$ by authors, all rights reserved. Authors agree that this article remains permanently open access under the terms of the Creative Commons Attribution License 4.0 International License

\begin{abstract}
The Ministry of Education's continuous effort in ensuring the success of education transformation requires the commitment of headmasters with instructional leadership qualities and high performing teachers. The role of instructional leadership is vital and can be a determinant of excellence and achievement of the desired education. There were three objectives of this study: (1) to identify the level of instructional leadership practice by the headmaster; (2) to identify the level of performance of the teachers; and (3) to identify the relationship between the level of instructional leadership practice and teacher performance. This study is a descriptive research using survey design involving 92 teachers of a National Primary School (Tamil) (SJKT) in Jasin, Melaka, Malaysia. The instrument was a questionnaire on teacher leadership instructional styles and teacher performance. Descriptive statistics (frequency) and inference statistics (Spearman's correlation test) have been used to answer the objectives of this study. The result showed that the level of instructional leadership of the headmasters and the level of performance of the teachers were high and there was a significant relationship between the headmaster instructional leadership practice and the performance of the teachers. Based on the findings of the study, it is proposed that the Ministry of Education Malaysian periodically and continuously conduct leadership training for all headmasters including SRJKT to improve the performance of teachers.
\end{abstract}

Keywords Instructional Leadership, Headmaster, Teacher Performance, Vernacular Schools

\section{Introduction}

Several changes have been made by the Ministry of Education Malaysia throughout Malaysia Educational Development Plan 2013-2025 to meet the global educational standard beyond 2020 [1]. To accomplish it, the leadership role played by the headmasters is very important in ensuring the effective management of the schools [2][3][4]. The Malaysian Educational Development Plan 2013-2025 has been formulated to ensure the successful implementation of the education system transformation.

The foundation of leadership in the school is based on instructional because teaching and learning is the main essence in determining student excellence. The Malaysian Ministry of Education has emphasized that instructional leadership plays a role in the development of teacher performance as well as planning, coordinating and evaluating teaching and learning activities in schools [1]. In this study Instructional Leadership is based on the Hallinger and Murphy Instructional Leadership Model [5]. According to [5], Instructional Leadership consists of three main aspects, namely defining school missions, managing instructional programs and creating a positive school climate.

Teacher performance refers to the actions, behaviors of work that can be measured or produced by teachers as well as relevant and contribute to the achievement of school or organizational goals. [6][7][8] found out that work motivation, salary, seriousness of work, knowledge, 
leadership and responsibilities, opportunities to pursue higher education, job satisfaction and the environment as factors that influence the performance of teachers. According to Buluyos et al. (2019), work performance is observed from the teacher's commitment to attend duty, compliance with school rules, work spirit, compilation of work at specified time and relationship with colleagues. In this study, teacher performance is based on the Work Performance Hierarchy Model by Campbell [9]. According to this model, teacher performance is determined based on declaration knowledge, knowledge of procedures and skills as well as motivation.

High-performing schools are significantly influenced by great leadership. Various leadership approaches can be practiced in schools according to the suitability and abilities of the leader [10][11][12]. Instructional leadership is appropriately practiced by school leaders towards bringing school excellence through educational change and innovation. In this regard, teacher performance is one of the dimensions that need to be considered towards building an excellent school [13]. Therefore, schools need to have leaders who practice instructional leadership. There are many past studies that have found that there is a relationship between instructional leadership and teacher performance. A study by [14] found that Headmasters who practice instructional leadership become agents of change and create a conducive school environment that has a positive impact on teacher performance and student achievement. The role of instructional leadership can also enhance the teachers' functional competency [15]. Instructional leadership has a significant impact on student academic achievement and teacher performance [16][17][18][19].

In reality, principals or headmasters are less effective at guiding teachers and sharing school goals [20]. Less clear goals make it difficult for teachers to share and achieve. In this regard, [11] asserts that clear goals can help school leaders ensure the effectiveness of the teaching and learning process by teachers. While [21] explained that school excellence depends on its leaders who share goals with teachers. A study by [22] found that school performance problems are due to weaknesses in leadership practices and lack of focus on curriculum management. Further research by [23] revealed that there are still many school headmasters in rural or small schools who are less proactive, less creative, less innovative, often lose focus as curriculum managers. Rapid changes in the field of education and the increasing workload have had implications for teachers' work performance. In relation to this, teachers actually expect guidance, support, help, encouragement and constructive advice from the headmaster. However, due to the busy factor with other tasks, the headmaster did not have time to discuss and communicate effectively with teachers related to teaching [24]. According to [25], the principal's supervision was strongly influenced by the ability of the principal to regulate the time and busyness of the work and the readiness of the teacher to be supervised.

This study contributes to the understanding of the relationship between headmaster instructional leadership and teachers' performance in the context of Tamil vernacular schools in Malaysia. Previous study by [26] only examines level of headmaster leadership in small schools, which includes Tamil National type school (SRJKT).

The objectives of this study are: (1) to identify the level of instructional leadership of headmasters; (2) to identify the level of teachers' work performance; and (3) the relationship between the level of instructional leadership of headmasters and the level of teachers' work performance.

\section{Methodology}

This is a quantitative study using survey methodology. The data were collected through a questionnaire on headmaster leadership instructional practices and their effect on teachers' work performance at SJKT at Jasin, Melaka.

SRJKT in Jasin district, Melaka was selected as the study location. SRJKT is one of the various types of government primary schools in Malaysia. The justification for this selection is based on the size of SRJKT is small and related to this, a study by [23] found that the performance of most small schools was low due to leadership weaknesses. Meanwhile, Jasin District was chosen because of its position in the State of Melaka which is a developed state in Malaysia. Its position in developed countries, the SRJKT should always show high performance.

The population of this study was teachers in 8 SJKTs located in Jasin district, Melaka, Malaysia. Based on the sample size determination of [27], a total of 92 respondents were selected from the total population of 120 teachers. The sampling technique used is a simple random sampling where sample selection is done based on random number tables. With the assistance and permission from school administration, questionnaires were administered and distributed to oddly numbered teachers based on the list of SRJKT teachers involved. They were given a week to answer and after a week I came back to collect questionnaires from the teachers.

The data obtained from the questionnaire were analysed using the Statistical Package for the Social Sciences (SPSS) version 22 . The use of mean value is a widely used method to describe the responses of all participants to the item in an instrument [28]. Statistics used are descriptive statistics of frequency, mean and percent to identify the level of instructional leadership among the headmaster and the level of teacher performance in SJKT around Jasin. While Spearman's correlation test (inference analysis) has been used to identify the relationship between the instructional leadership of the headmasters and the performance of 
teachers in SJKT.

A pilot study was conducted at an SRJKT in the Central Melaka District where a total of 30 teachers were randomly selected as respondents. The implementation of the pilot study is to test the level of reliability and validity of the constructs in the research instrument so that the data collected from the actual study can be trusted.

Prior to the pilot study, the validity of the questionnaire content was obtained from the review and approval of the instrument expert. Slight modification of the questionnaire items was done based on expert suggestions and comments. Information from the pilot study was analyzed using Statistical Package for Social Sciences version 16. Data were checked for validity and reliability using Cronbach Alpha. The value of the Cronbach Alpha coefficient for headmaster instructional leadership practice instruments as a whole is high at 0.972 . Similarly, the Cronbach Alpha coefficient for the teacher performance instrument as a whole is high at 0.959 . There were three items that were improved upon when item correlation values were identified as less than 0.6.

The research instrument used in this study is a questionnaire based on the Instructional Leadership Model element by [5] and [29]. This questionnaire consists of Part 1: general information (demographics), Part 2 (Instructional Leadership Practice): i. Creating school goals, ii. Delivering school goals, iii. Supervising and evaluating teaching, iv. Monitoring student progress, v. Protecting instructional time and vi. Promoting professional development. Meanwhile Part 3 (Teacher Work Performance) is made of the following aspects: i. Declaration knowledge, ii. Procedural knowledge and skills, and iii. Motivation.

\section{Results \& Discussion}

The findings of the study analysis show that the level of instructional leadership of the headmaster at Jasin District SJKT is at a high level overall with mean value of 4.52 and the standard deviation is 0.35 (Table 1). For the performance level of teachers, the overall mean value was at a high level of 4.53 and the standard deviation (sd) was 0.43 . The strength level of the correlation coefficient value is based on [30].

\subsection{Instructional Leadership Level}

Result of the first objective is summarised in the following table.

Table 1. Instructional Leadership Levels and Teacher Performance Levels

\begin{tabular}{|c|c|c|}
\hline & $\begin{array}{c}\text { Instructional } \\
\text { Leadership }\end{array}$ & $\begin{array}{c}\text { Teacher's Work } \\
\text { Performance }\end{array}$ \\
\hline Valid & 92 & 92 \\
\hline Missing & 0 & 0 \\
\hline Mean & 4.5243 & 4.4312 \\
\hline Standard Deviation & .35457 & .42744 \\
\hline
\end{tabular}

The findings of the study analysis show the level of instructional leadership of the headmaster at Jasin District SJKT, in six dimensions based on [5]. Overall, all six dimensions have a very high mean value (Table 2). Among them, the dimensions of promoting professional development are very high $($ mean $=4.59$, sd $=0.43)$. This shows that the headmaster plays an important role in the development of professionalism of his teachers. The dimensions devise school goals are the second highest (mean $=4.55$, sd $=0.41)$. While delivering school goals is the third highest dimension $($ mean $=4.54, \mathrm{sd}=0.41$ ).

Table 2. Instructional Leadership Levels by Six Dimensions

\begin{tabular}{|c|c|c|c|c|}
\hline Instructional Leadership Dimension & $\mathrm{N}$ & Mean & Standard Deviation & Meam Interpretation \\
\hline Developing school goal & 92 & 4.5500 & .40829 & High \\
\hline $\begin{array}{c}\text { Delivering school goals Supervise and evaluate } \\
\text { teaching }\end{array}$ & 92 & 4.5391 & .41376 & High High \\
\hline $\begin{array}{c}\text { Supervise and evaluate teaching } \\
\text { Monitor student progress }\end{array}$ & 92 & 4.4848 & .44989 & High \\
\hline Protecting instructional time & 92 & 4.4522 & .49514 & High \\
\hline Encourage professional development & 92 & 4.5891 & .47573 & High \\
\hline TOTAL & & 4.5243 & .35457 & HIGH \\
\hline
\end{tabular}




\subsection{Teacher Work Performance}

Table 3 shows the level of teacher's work performance in three elements consisting of declaration knowledge, procedural knowledge and skills, and motivation. Among them, the declaration knowledge shows a high mean (min $=4.53, \mathrm{sp}=.46)$. This datum explains that the knowledge on how to perform an assignment greatly influences teachers in improving their work performance.

Table 3. Level of Teacher Work Performance

\begin{tabular}{|c|c|c|c|}
\hline & $\begin{array}{c}\text { Declarative } \\
\text { Knowledge }\end{array}$ & $\begin{array}{c}\text { Procedure \& } \\
\text { Skills } \\
\text { Knowledge }\end{array}$ & Motivation \\
\hline Valid & 92 & 92 & 92 \\
\hline Missing & 0 & 0 & 0 \\
\hline Mean & 4.5348 & 4.5283 & 4.5304 \\
\hline $\begin{array}{c}\text { Standard } \\
\text { Deviation }\end{array}$ & .46230 & .48772 & .51221 \\
\hline
\end{tabular}

\subsection{Relationship between Level of Instructional Leadership and Level of Work Performance}

Spearman's correlation test results show the relationship between instructional leadership practice and teacher work performance (Table 4). The results of the correlation analysis showed a strong correlation between instructional leadership and teacher work performance $(r=.76, p<.01)$ It is found that instructional leadership element of encouraging professional development has a strong influence on the work performance of teachers. The results of this analysis suggest that the instructional leadership of the headmaster is a key factor in improving the performance of teachers in their organizations. The headmaster who encourages professional development of teachers not only guides teachers to a high level of professionalism but directly develops the overall work performance of teachers.

The findings show that there is a significant relationship between the instructional leadership of headmaster and the work performance of teachers in SJKT Jasin District, Melaka. This means that the instructional leadership of the headmaster greatly influences the work performance of the teacher without distinguishing between gender, age, teaching experience and grade of post. Based on the results of the study, it was found that the headmasters strongly encouraged the professional development of teachers. This means that teachers' achievements can be enhanced by encouraging professional development of teachers.

The finding of this study supports the instructional leadership theory which emphasizes that the practice of instructional leadership of the headmaster consists of three main dimensions which are defining the school goals, managing school curricula and teaching and also cultivating a warm teaching and learning environment [5]. Instructional leadership also includes the role of the headmaster as resource suppliers, teaching resources, and communication people [12]. Successful leaders are leaders who have the vision and are capable of developing a solid view, in line with the goals that can bring their organization to success [2]. According to [31], successful school leadership is headmasters who act as leaders which can set the ambient for better teacher quality and performance. In addition, this study supports the findings by [32] that friendly communication with teachers is able to encourage teachers' thinking and development professionally thus more effective. Furthermore, [33] states that the superior leadership of the headmaster is based on the creation of a strong vision and strategy. A visionary headmaster who has a good line of sight is more focus, making careful monitoring, assessing achievements and taking follow-up actions [12].This behaviour is in line with the study conducted by [34] and [35] who state that the headmaster who involved in various activities could enable them to set up an organizational goal, set the direction of the school and redesign the organization. Therefore, it is no surprise that the headmasters who practice instructional leadership are able to improve the performance of teachers, students and schools. In that regard, if a school wants to enhance the performance of teachers, then the headmaster should practice the instructional leadership. The instructional leadership of the headmaster is the key to determine the effectiveness of teacher performance in a threedimensional school that defines school goals, manages curriculum and school teaching and fosters a teaching and learning climate. Among them, declarative knowledge $(\min =4.53)$ is an element that greatly influences teacher's work performance. This means that the informative knowledge on the execution of tasks and information about it is very important for teachers to perform the task effectively and as desired. Teachers with clear knowledge of the entrusted assignments can certainly perform easily and well. 
Table 4. Practical Leadership Practices Leadership Practice with Teacher Work Performance

\begin{tabular}{|c|c|c|c|c|}
\hline & & Correlation & Instructional Leadership & $\begin{array}{l}\text { Teacher's Work } \\
\text { Performance }\end{array}$ \\
\hline \multirow{6}{*}{$\begin{array}{l}\text { Spearman's } \\
\text { rho }\end{array}$} & \multirow{3}{*}{ Instructional Leadership } & Correlation Coefficient & 1.000 & $.757 * *$ \\
\hline & & Sig.(2-tailed) & - & .000 \\
\hline & & $\mathrm{N}$ & 92 & 92 \\
\hline & \multirow{3}{*}{$\begin{array}{l}\text { Teacher's Work } \\
\text { Performance }\end{array}$} & Correlation Coefficient & $.757 * *$ & 1.000 \\
\hline & & Sig.(2-tailed) & .000 & - \\
\hline & & $\mathrm{N}$ & 92 & 92 \\
\hline
\end{tabular}

** Correlation is significant at the 0.01 level (2-tailed)

\section{Conclusions \& Suggestions}

All the three dimensions of the instructional leadership represent effective and quality leadership practices among the headmasters who wish to ensure the performance of teachers in schools. The overall findings have been successful in identifying the relationship between teacher leadership instructional practices and their effect on teacher performance in school. The instructional leadership elements of formulating school goals, delivering school goals, supervising and evaluating teaching, monitoring student progress, protecting instructional times and promoting professional development influence teacher work performance. The findings of this study serve as a reference for the headmasters on the practices of instructional leadership and ensure effective teacher work performance.

Based on the findings of this study, it is proposed that the Ministry of Education Malaysia organizes programs related to building instructional leadership skills among school leaders on a regular and continuous basis. Similarly, school leaders need to proactively strive to improve their ability to implement instructional leadership because the findings of the study clearly show that instructional leadership practices have a significant relationship with teacher performance.

Since this study was conducted in only three SRJKTs in the Jasin District of Melaka, it is proposed that further studies be extended to various other schools such as SRJKC and SMKA in other districts or states so that the findings can be generalized throughout Malaysia. Similarly, research methods can be further diversified, for example using both mix method methods, namely quantitative and qualitative methods with appropriate weighting.

\section{Acknowledgements}

This research was supported by the grant from the
Faculty of Education, Universiti Kebangsaan Malaysia (GG2018-011).

\section{REFERENCES}

[1] Malaysian Ministry of Education, Malaysia Education Blueprint 2013-2025, Putrajaya: MOE, 2013.

[2] K. Leithwood., J. Sun, \& K. Pollock (Eds.), How school leaders contribute to student success: The four paths framework, vol. 23, Springer, 2017.

[3] W. Wahyuddin, "Headmaster leadership and teacher competence in increasing student achievement in school", International Education Studies, vol. 10, no. 3, pp. 215-226, 2017.

[4] K. R. Buckner, Leadership Practices of Female Principals, (Unpublished Ph.D. thesis), Capella University, 2011.

[5] P. Hallinger \& J. Murphy, Organizational and Social Context and the Instructional Leadership Role of the School Principal, 1987.

[6] T. S. Dee \& J. Wyckoff, "Incentives, selection, and teacher performance: Evidence from IMPACT”, Journal of Policy Analysis and Management, vol. 34, no. 2, pp. 267-297, 2015.

[7] C. Ratnasih, "Leadership Style, Discipline, Motivation and the implications of Teachers' Performance", International Journal of Human Capital Management, vol. 1, no. 1, pp. 124-135, 2017.

[8] S. T. Muhamad \& M. Mazlan, "Pengaruh dimensi kepimpinan instruksional pengetua terhadap komitmen kerja guru di Sabah", Prosiding Seminar Kebangsaan Kali ke IV Majlis Dekan IPTA, 2013, pp. 449-457, Gombak: Universiti Islam Antarabangsa, 2013.

[9] S. Sonnentag, J. Volmer \& A. Spychala, Job performance. The Sage handbook of organizational behavior, vo1. 1, pp. 427-447, 2008.

[10] M. Fullan, "The nature of leadership is changing", European Journal of Education, vol. 55, no. 2, pp. 139-142, 2020. 
[11]P. Hallinger, "Science mapping the knowledge base on educational leadership and management from the emerging regions of Asia, Africa and Latin America, 1965-2018”, Educational Management Administration \& Leadership, vol. 48, no. 2, pp. 209-230, 2020.

[12] Mohammed Sani Ibrahim \& Jamalullail Abdul Wahab, Kepimpinan Pendidikan, Bangi: Universiti Kebangsaan Malaysia, 2012.

[13] Menaha a/p Ramasamy \& Jamalulail Abdul Wahab, “Amalan kepimpinan instruksional guru besar di Sekolah Kebangsaan Daerah Kuala Langat", Kuala Lumpur International Conference Proceeding on Business, Education, Social Sciences \& Technology, pp. 70-77, 2020.

[14] I. A. Tatlah, S. N. Akhtar \& M. A Hashmi, "Effect of instructional leadership on teachers' performance and job commitment: A comparison of public and private universities of Lahor", Journal of Educational Research, vol. 22, no. 1, pp. 133, 2019.

[15] Siti Noor Ismail, Shamsuddin Muhammad, Mohd Norakmar Omar, Arumugam Raman, "The Great Challenge of Malaysian School Leaders' Instructional Leadership: Can It Affect Teachers' Functional Competency across 21 st Century Education?", Universal Journal of Educational Research, vol. 8, no. 6, pp. 2436 - 2443. DOI: 10.13189/ujer.2020.080627, 2020 .

[16] P. Hallinger \& R. Hosseingholizadeh, "Exploring instructional leadership in Iran: A mixed methods study of high-and low-performing principals", Educational Management Administration \& Leadership, $1741143219836684,2019$.

[17] A. Zahed-Babelan, G. Koulaei, M. Moeinikia \& A. R. Sharif, 'Instructional leadership effects on teachers' work engagement: roles of school culture, empowerment, and job characteristics", CEPS Journal, vol. 9, no. 3, pp. 137-156, 2019.

[18] Nadia Abdul Hamid, Amalan kepimpinan instruksional dan sikap terhadap perubahan dalam kalangan pengetua di sekolah berprestasi tinggi, Tesis sarjana Universiti Kebangsaan Malaysia, 2017.

[19] M. Pietsch \& P. Tulowitzki, "Disentangling school leadership and its ties to instructional practices-an empirical comparison of various leadership styles", School Effectiveness and School Improvement, vol. 28, no. 4, pp. 629-649, 2017.

[20] Alimuddin Mat Dom, Ciri-ciri pengetua yang outstanding. Selangor: Widad Publications, 2010.

[21] K. Schildkamp, C. L. Poortman, J. Ebbeler \& J. M. Pieters, "How school leaders can build effective data teams: Five building blocks for a new wave of data-informed decision making", Journal of Educational Change, vol. 20, no. 3, pp. 283-325, 2019.

[22] M. Makgato \& N. N. Mudzanani, "Exploring school principals' leadership styles and learners' educational performance: A perspective from high-and low-performing schools", Africa Education Review, vol.16, no. 2, pp. 90-108, 2019.

[23] Azlin Norhaini Mansor, Aida Hanim A Hamid, Nitce Isa Medina, Sharmini Siva Vikaraman, Jamalul Lail Abdul
Wahab, Mohamed Yusoff Mohd Nor \& Bity Salwana Alias, "Challenges and strategies in managing small schools: A case study in Perak, Malaysia", Educational Management Administration \& Leadership, pp. 1-17, 2020.

[24] R. Q. Danish, S. Qaseem, T. Mehmood, Q. M. Ali, H. F. Ali \& R. Shahid, "Work related stressors and teachers' performance: evidence from college teachers working in Punjab", European Scientific Journal (ESJ), vol. 1, no. 4, pp. $158-173,2019$

[25] Tati Nurhayati, Moh. Masnun, Tamsik Udin, Ahmad Arifuddin, "Implementation of Principal Supervision as an Effort to Fulfill Teacher Administration at Islamic Elementary School", Universal Journal of Educational Research, vol. 7, no. 8, pp. 1826 - 1831. DOI: 10.13189/ujer.2019.070822, 2019.

[26] Nitce Isa Medina, Azlin Norhaini Mansor, Jamalul Lail Abdul Wahab, Sharmini Siva Vikaraman, "Principals' Instructional Leadership in Small School-A Preliminary Study.", International Journal of Academic Research in Business and Social Sciences, vol. 8, no. 8, 2018.

[27] R. V. Krejcie \& D. W. Morgan, "Determining sample size for research activities", Educational and Psychological Measurement, vol. 30, no. 3, pp. 607-610, 1970.

[28] J. W. Creswell, Educational research: planning, conducting, and evaluating, quantitative and qualitative and research. Ed. ke-4, Lincoln: Pearson Merrill Prentice Hall, 2012.

[29] J. P. Campbell, "Modeling the performance prediction problem in industrial and organizationa lpsychology", in M. Dunnette and L. M. Hough (eds.), Handbook of Industrial and

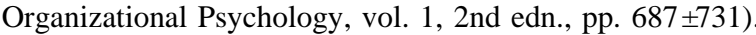
PaloAlto, CA: Consulting Psychologists Press, 1990.

[30] Y. P. Chua, Kaedah dan Statistik Penyelidikan (Buku 2): Asas Statistik Penyelidikan, Selangor. The McGraw Hill. Companies, 2012.

[31] D. Gurr, L. Drysdale, F. Longmuir \& K. McCrohan, "Successful school leadership that is culturally sensitive but not context constrained", In Educational Leadership, Culture, and Success in High-Need Schools (pp. 25-43), Information Age Publishing, 2019.

[32] J. Blasé \& J. Blasé, "Effective instructional leadership: Teachers' perspectives on how principals promote teaching and learning in schools", Journal of Educational Administration, vol. 38, no. 2, pp. 130-141, 1999.

[33] R. Aryanti \& D. Suhardan, "Principal leadership and school committee administrators against school-based management effectiveness", In 3rd International Conference on Research of Educational Administration and Management (ICREAM 2019), pp. 151-152, Atlantis Press, 2020.

[34] A. Istikaroh, "Qualification and competence of headmaster as a supervisor according to Regulation of The Minister of National Education Number 13 of 2007 to face Industry 4.0", In International Conference of Moslem Society, vol. 3, pp. 348-360), 2019.

[35] M. Ubaidillah, R. Christianan \& A. Sahrandi, "Visionary leadership strategies in advancing educational institutions", Erudio Journal of Educational Innovation, vol. 6, no. 2, pp. 206-215, 2019. 